\title{
Peran Perusahaan BUMN dalam Mengakomodasi Kebutuhan Masyarakat Melalui Kegiatan CSR
}

\author{
Raditia Yudistira Sujanto \\ Universitas 'Aisyiyah Yogyakarta \\ E-mail: sujanto.raditia@unisayogya.ac.id \\ *corresponding author
}

Keywords:

corporate social responsibility, temple tourism parks, PKBL, CSR $B U M N$

\section{Kata Kunci:}

tanggung jawab sosial perusahaan, taman wisata candi, PKBL, CSR $B U M N$

\begin{abstract}
PT TWC carries out corporate social responsibility activities through a special division namely PKBL. Social programs implemented are mainly of philanthropic activities such as providing assistance such as educational funding for high-achieving students, house renovation for members of the community in need, and assistance for employees who are fully dedicated to the company. This research uses a quantitative approach with interview techniques with the PKBL Division Manager and documentation studies on the company's official social media where the PKBL team publishes the social programs that have been implemented. This research found that PT TWC through the PKBL Division of corporate social responsibility programs is still conventional in nature and not relevant enough to the company's operational activities that focus on temple tourism parks. PT TWC should be able to involve the community in the process of program formulation through open dialogue so that the issues that become the basis of material of the social programs can be truly targeted both in terms of the community being targeted and the priority of the issue itself. Future studies can use other research techniques such as observation and interviews with the community around the company to get a perception of PT TWC.
\end{abstract}

\begin{abstract}
ABSTRAK
PT TWC melaksanakan kegiatan tanggung jawab sosial perusahaan melalui divisi khusus yaitu PKBL. Program-program sosial yang dilaksanakan lebih kental pada kegiatan yang bersifat filantrofis seperti pemberian bantuan seperti bantuan dana pendidikan bagi siswa berprestasi, bedah rumah bagi anggota masyarakat yang membutuhkan, dan bantuan bagi pegawai yang berdedikasi penuh pada perusahaan. Penelitian ini menggunakan pendekatan kuantitatif dengan teknik wawancara dengan Manajer Divisi PKBL dan studi dokumentasi pada media sosial resmi perusahaan di mana tim PKBL mempublikasikan program-program sosial yang telah dilaksanakan. Peneliti menemukan bahwa PT TWC melalui Divisi PKBL program-program tanggung jawab sosial perusahaan masih bersifat konvensional dan tidak cukup relevan dengan aktivitas operasional perusahaan yang fokus pada taman wisata candi. Sebaiknya PT TWC dapat melibatkan masyarakat dalam proses perumusan program melalui dialog terbuka sehingga isu-isu yang menjadi bahan program sosial dapat benar-benar tepat sasaran baik dari segi masyarakat yang menjadi sasaran maupun prioritas isu itu sendiri. Penelitian selanjutnya dapat menggunakan teknik penelitian lain seperti observasi dan wawancara dengan masyarakat sekitar perusahaan untuk mendapatkan persepsi terhadap PT TWC.
\end{abstract}

Copyright (C) 2019 Channel Jurnal Komunikasi. All right reserved. 


\section{PENDAHULUAN}

Isu perhatian terhadap lingkungan sosial dan lingkungan hidup telah menjadi perhatian bersama di tingkat global seperti tertera dalam rumusan Sustainable Development Goals (SDGs). Tidak hanya ini menjadi tanggung jawab kelompok tertentu, perhatian terhadap isu sosial dan lingkungan hidup menjadi tanggung jawab semua kalangan, baik itu instansi pemerintah, bisnis maupun lembaga swadaya masyarakat (LSM). ISO26000:2010 menjadi salah satu panduan yang digunakan secara global mengenai pelaksanaan tanggung jawab sosial. Terdapat tujuh subyek inti yang menjadi pembahasan di dalamnya di mana terdapat sejumlah isu, mulai dari subyek pengelolaan kelembagaan/keorganisasian sampai subyek pengembangan dan keterlibatan masyarakat.

Secara umum, pembahasan mengenai tanggung jawab sosial perusahaan dapat ditarik ke dalam perspektif yang cukup kritis -dalam artian tanggung jawab sosial perusahaan bukan hanya saja sebatas pembatalan janji hukum dan etika sosial, melainkan benar-benar menjadi kebutuhan bagi perusahaan itu sendiri. Dari penelitian yang sebelumnya mengenai tanggung jawab sosial perusahaan, tidak sedikit program sosial yang dilaksanakan tidak didasarkan pada kebutuhan utama masyarakat yang menjadi sasaran program, melainkan hanya sekadar pembatalan janji perusahaan bahwa tanggung jawab sosial telah dilaksanakan.

Dikutip dari sebuah artikel dalam Jurnal Public Relations dengan judul Conspicuous Corporate Social Responsibility, disebutkan bahwa organisasi atau perusahaan yang memiliki perilaku bertanggungjawab secara sosial berbasis masyarakat memiliki otonomi yang kuat dan mampu membangun hubungan berbasis kepercayaan dengan para publiknya (Rawlins, 2005, dalam Verčič dan Zerfass, 2016). Dikutip dalam artikel jurnal penelitian Arba'in Ridho Afiansyah, menurut Busyra Azheri perusahaan tidak hanya berdiri sebagai entitas yang mementingkan diri sendiri dan/ atau melakukan eksklusivitas dari lingkungan sekitar dan masyarakat, tetapi sebagai sebuah entitas berbadan hukum yang berkewajiban untuk melakukan adaptasi sosio-kultural dengan lingkungan di mana ia berada (Azheri, 2012, dalam Afiansyah, 2015). Bukan hal yang salah jika perusahaan fokus memaksimalkan profit atau keuntungan finansialnya, tapi harus terdapat keseimbangan. Keseimbangan yang dimaksud disebutkan oleh Porter dan Kramer (2002) melalui pembahasan triple bottom lines atau dapat juga disebut 3Ps, yaitu Profit, People, dan Planet. Profit, perusahaan berorientasi untuk mencari keuntungan finansial agar dapat terus bertahan hidup dan mengembangkan diri. People, keberadaan perusahaan turut mempedulikan tingkat kesejahteraan masyarakat yang menjadi publik perusahaan. Planet, perusahaan menunjukkan kepeduliannya terhadap lingkungan hidup.

Program tanggung jawab sosial menjadi perhatian bersama dan telah diatur di beberapa panduan dan bahkan Undang-Undang seperti UU No.40 tahun 2007 tentang Perseoran Terbatas. Pada penelitian berikut, pengelola PT. Taman Wisata Candi Borobudur, Prambanan dan Ratu Boko (selanjutnya akan disebut TWC) yang berpusat di provinsi Jawa Tengah menjadi obyek penelitian. Aktivitas tanggung jawab sosial menjadi hal yang menarik karena berbeda dari penelitian-penelitian peneliti sebelumnya, TWC adalah badan usaha milik negara (BUMN) yang bergerak di bidang pengelolaan tempat wisata candi di Indonesia terutama Candi Borobudur, Candi Prambanan dan Candi Ratu Boko. Pada penelitian-penelitian sebelumnya, peneliti menaruh perhatian pada perusahaan bisnis swasta yang berorientasi pada pelayanan dan pemasaran daring. Kali ini, penelitian akan dilakukan pada organisasi yang dinaungi pemerintah dan bergerak di bidang pengelolaan situs purbakala yaitu candi.

TWC merupakan badan usaha milik negara (BUMN) yang bergerak di bidang pariwisata dengan nama resmi PT. Taman Wisata Candi Borobudur, Prambanan dan Ratu Boko (Persero). Seperti yang tersirat di dalam namanya, TWC menangani pengelolaan tiga candi yaitu Candi Borobudur, Candi Prambanan, dan Candi Ratu Boko. Secara khusus, program tanggung jawab sosial TWC berada di bawah Divisi Program Kemitraan dan Bina Lingkungan (PKBL). Dengan demikian penelitian ini akan dilaksanakan pada divisi PKBL TWC. Ketertarikan peneliti terhadap kegiatan sosial TWC melalui divisi PKBL terdapat pada pemetaan program-program sosialnya itu sendiri. Jika secara teoritis disebutkan bahwa setiap kegiatan komunikasi pasti memiliki tujuan, maka kegiatan-kegiatan sosial yang dilaksanakan oleh PKBL tidak lepas dari tujuan yang ingin dicapai. Tidak hanya berhenti pada pemetaan program dan tujuan, penelitian ini juga akan menelusuri bagaimana proses identifikasi isu program sosial dilaksanakan dan juga bagaimana kemudian hasil-hasil dari kegiatan sosial yang ada dikomunikasikan kepada publik melalui media-media tertentu.

\section{TINJAUAN PUSTAKA}

\section{A. Investasi Sosial}

Penamaan istilah mengenai hal-hal yang bernuansa investasi sosial atau masyarakat bisa cukup membingungkan. Hal tersebut dikarenakan banyak organisasi yang menggunakan istilah tersebut namun dengan rujukan ke filantrofi (philanthropy), pemberian dana untuk amal (charitable giving), tanggung jawab sosial perusahaan (corporate social responsibility), program masyarakat (community programs) dan kontribusi sosial (social contributions). Pada dasarnya tidak ada standar penamaan resmi mengenai investasi sosial. Akan tetapi, tiga nama yang paling umum digunakan oleh perusahaan-perusahaan adalah investasi masyarakat (community investment), investasi sosial (social investment), dan filantrofi (philanthropy) (KPMG International, 2014). Investasi sosial dipandang sebagai kegiatan investasi yang dilakukan oleh sebuah organisasi atau perusahaan untuk berkontribusi untuk masyarakat tanpa ada maksud langsung 
untuk memperoleh keuntungan finansial.

Beberapa pengertian mengenai investasi sosial oleh KPMG International (2014) meliputi:

1. Investasi dalam bentuk donasi perusahaan berupa uang tunai atau produk, employee volunteering, dan pemberian sponsor (sponsorship);

2. Investasi yang dibuat langsung oleh perusahaan, ditujukan kepada rekan perusahaan yang tidak berbasis profit (non-for-profit partners);

3. Investasi yang dilakukan secara sukarela, termasuk pelaksanaan program-program yang diharuskan oleh pemerintah;

4. Investasi yang dilakukan secara lokal, dekat dengan aktivitas operasional perusahaan, dan seringkali dengan tujuan ingin mempererat hubungan antara perusahaan dan masyarakat setempat yang terpengaruh oleh aktivitas operasional perusahaan; dan

5. Investasi yang dilakukan secara global atau mendunia dan ditargetkan untuk keuntungan-keuntungan beberapa negara.

\section{B. Corporate Social Responsibility (CSR)}

Johnson dan Johnson (2006) dalam Hadi (2014) mendefinisikan "corporate social responsibility (CSR) is about how companies manage the business processes to produce an overall positive impact on society." Diartikan, Tanggung jawab sosial perusahaan adalah tentang bagaimana perusahaan mengelola proses bisnisnya guna menghasilkan dampak positif bagi masyarakat. Ghana (2006) dalam Hadi (2014) menyebutkan bahwa CSR adalah tentang bagaimana perusahaan memberikan kembali kepada masyarakat.

Hadi (2014) dalam bukunya menampilkan tabel yang berisi prinsip-prinsip corporate social responsibility menurut Alyson Warhust dari University of Bath Inggris (1998). Peneliti menilai bahwa prinsip-prinsip tersebut berkaitan dengan tabel 2.1 berisi argumen yang mendukung tanggun jawab sosial. Berikut adalah prinsip-prinsip CSR menurut Alyson.

Tabel 1. Prinsip-prinsip Corporate Social Responsibility

\begin{tabular}{|c|c|c|}
\hline No. & Prinsip & Uraian \\
\hline 1 & Prioritas Korporat & $\begin{array}{l}\text { Mengakui tanggung jawab sosial sebagai prioritas tertinggi perusahaan, } \\
\text { sehingga segala aktivitas (operasi) perusahaan tak dapat dilepas dari } \\
\text { tanggung jawab sosial. }\end{array}$ \\
\hline 2 & Manajemen Terpadu & $\begin{array}{l}\text { Mengintegrasikan kebijakan, program dan praktik ke dalam setiap } \\
\text { kegiatan bisnis sebagai satu unsur manajemen dalam semua fungsi. }\end{array}$ \\
\hline 3 & Proses Perbaikan & $\begin{array}{l}\text { Secara berkesinambungan memperbaiki kebijakan, program dan kinerja } \\
\text { sosial korporat, berdasarkan temuan riset mutakhir dan memahami } \\
\text { kebutuhan sosial serta menerapkan kriteria sosial tersebut secara } \\
\text { internasional. }\end{array}$ \\
\hline 4 & Pendidikan Karyawan & Menyelenggarakan pendidikan dan pelatihan serta memotivasi karyawan. \\
\hline 5 & Pengkajian & $\begin{array}{l}\text { Melakukan kajian dampak sosial sebelum memulai kegiatan atau proyek } \\
\text { baru dan sebelum menutup satu fasilitas atau meninggalkan lokasi proyek. }\end{array}$ \\
\hline 6 & Produk dan Jasa & $\begin{array}{l}\text { Mengembangkan produk dan jasa yang tidak berdampak negatif terhadap } \\
\text { lingkungan. }\end{array}$ \\
\hline 7 & Informasi Publik & $\begin{array}{l}\text { Memberi informasi dan (bila diperlukan) mendidik pelanggan, distributor } \\
\text { dan publik tentang penggunaan yang aman, dan begitu pula dengan jasa. }\end{array}$ \\
\hline 8 & Fasilitas dan Operasi & $\begin{array}{l}\text { Mengembangkan, merancang, dan mengoperasikan fasilitas serta } \\
\text { menjalankan kegiatan yang mempertimbangkan temuan kajian dampak } \\
\text { lingkungan. }\end{array}$ \\
\hline 9 & Penelitian & $\begin{array}{l}\text { Melalukan atau mendukung penelitian dampak sosial bahan baku, } \\
\text { produk, proses, emisi dan limbah yang terkait dengan kegiatan usaha dan } \\
\text { penelitian yang menjadi saran mengurangi dampak negatif. }\end{array}$ \\
\hline 10 & Prinsip Pencegahan & $\begin{array}{l}\text { Memodifikasi manufaktur, pemasaran atau penggunaan produk dan jasa, } \\
\text { sejalan dengan penelitian mutakhir untuk mencegah dampak sosial yang } \\
\text { bersifat negatif. }\end{array}$ \\
\hline 11 & Kontraktor dan Pemasok & $\begin{array}{l}\text { Mendorong penggunaan prinsip-prinsip tanggung jawab sosial korporat } \\
\text { yang dijalankan kalangan kontraktor dan pemasok, di sampai itu bila } \\
\text { diperlukan masyarakat perbaikan dalam praktik bisnis yang dilakukan } \\
\text { kontraktor dan pemasok. }\end{array}$ \\
\hline
\end{tabular}




\begin{tabular}{|c|l|l|}
\hline 12 & Siaga Menghadapi Darurat & $\begin{array}{l}\text { Menyusun dan merumuskan rencana menghadapi keadaan darurat, dan } \\
\text { bila terjadi keadaan bahaya bekerja sama dengan layanan gawat darurat, } \\
\text { instansi berwenang dan komunitas lokal. Sekaligus mengenali potensi } \\
\text { bahaya yang muncul. }\end{array}$ \\
\hline 13 & Transfer Best Practice & $\begin{array}{l}\text { Berkontribusi pada pengembangan kebijakan publik dan bisnis, lembaga } \\
\text { pemerintah dan lintas departemen pemerintah serta lembaga pendidikan } \\
\text { yang akan meningkatkan kesadaran tentang tanggung jawab sosial. }\end{array}$ \\
\hline 14 & Memberi Sumbangan & $\begin{array}{l}\text { Sumbangan untuk usaha bersama, pengembangan kebijakan publik } \\
\text { dan bisnis, lembaga pemerintah dan lintas departemen pemerintah } \\
\text { serta lembaga pendidikan yang akan meningkatkan kesadaran tentang } \\
\text { tanggung jawab sosial. }\end{array}$ \\
\hline 15 & Keterbukaan & $\begin{array}{l}\text { Menumbuhkembangkan keterbukaan dan dialog dengan pekerja dan } \\
\text { publik, mengantisipasi dan memberi respon terhadap potential hazard } \\
\text { dan dampak operasi, produk dan limbah atau jasa. }\end{array}$ \\
\hline 16 & Pencapaian dan Pelaporan & $\begin{array}{l}\text { Mengevaluasi kinerja sosial, melaksanakan audit sosial secara berkala } \\
\text { dan mengkaji pencapaian berdasarkan kriteria korporat dan peraturan } \\
\text { perundang-undangan dan menyampaikan informasi tersebut pada dewan } \\
\text { direksi, pemegang saham, pekerja dan publik. }\end{array}$ \\
\hline
\end{tabular}

Tanggung jawab sosial (social responsibility), menurut Robbins \& Coutler (2010) didefinisikan sebagai intensi bisnis, melampaui kewajiban hukum dan ekonominya, untuk melakukan hal yang benar dan bertindak dengan cara yang baik bagi masyarakat.

Tabel 2. Argumen yang Mendukung Tanggung Jawab Sosial

\begin{tabular}{|c|l|}
\hline 1 & Ekspektasi Publik - Opini publik sekarang mendukung bisnis yang mengejar tujuan ekonomi dan sosial \\
\hline 2 & $\begin{array}{l}\text { Profit Jangka Panjang - Perusahaan bertanggungjawab secara sosial cenderung mempunyai profit jangka } \\
\text { panjang yang lebih pasti }\end{array}$ \\
\hline 3 & $\begin{array}{l}\text { Kewajiban Etis - Bisnis harus mempunyai tanggung jawab sosial karena tindakan yang bertanggungjawab } \\
\text { merupakan hal yang benar untuk dilakukan }\end{array}$ \\
\hline 4 & Citra Publik - Bisnis dapat menciptakan citra publik yang baik dengan mengejar tujuan sosial \\
\hline 5 & Lingkungan yang Lebih Baik - Keterlibatan bisnis dapat membantu pemecahan masalah sosial yang sulit \\
\hline 6 & $\begin{array}{l}\text { Pelonggaran Peraturan Pemerintah - Dengan bertanggungjawab secara sosial, bisnis dapat mengharapkan } \\
\text { berkurangnya peraturan pemerintah }\end{array}$ \\
\hline 7 & $\begin{array}{l}\text { Penyeimbang Tanggung Jawab dan Kekuasaan - Bisnis mempunyai banyak kekuasaan dan tanggung } \\
\text { jawab yang sama besarnya diperlukan untuk menandingi kekuasaan tersebut }\end{array}$ \\
\hline 8 & $\begin{array}{l}\text { Kepentingan Pemegang Saham - Tanggung jawab sosial akan meningkatkan harga saham dalam jangka } \\
\text { panjang }\end{array}$ \\
\hline 9 & $\begin{array}{l}\text { Penguasaan Sumber Daya - Bisnis mempunyai sumber daya untuk mendukung proyek publik dan proyek } \\
\text { amal yang membutuhkan bantuan }\end{array}$ \\
\hline 10 & $\begin{array}{l}\text { Mengutamakan Pencegahan Daripada Perbaikan - Bisnis seharusnya mengatasi masalah sosial sebelum } \\
\text { mereka menjadi lebih serius dan makin mahal untuk diperbaiki }\end{array}$ \\
\hline
\end{tabular}

Penelitian ini juga menggunakan standar-standar dalam ISO 26000:2010 sebagai panduan untuk membantu proses identifikasi kontribusi sosial perusahaan yang menjadi objek penelitian ini, seperti yang tertera dalam Tabel 2.3 berikut. 
Tabel 3. Subjek inti dan isu-isu tanggung jawab sosial (ISO 26000:2010)

\begin{tabular}{|c|c|}
\hline Subjek Inti & Isu \\
\hline Human rights & $\begin{array}{l}\text { Issue 1: Due diligence } \\
\text { Issue 2: Human rights risk situations } \\
\text { Issue 3: Avoidance of complicity } \\
\text { Issue 4: Resolving grievances } \\
\text { Issue 5: Discrimination and vulnarable groups } \\
\text { Issue 6: Civil and political rights } \\
\text { Issue 7: Economic, social and cultural rights } \\
\text { Issue 8: Fundamental principles and rights at work }\end{array}$ \\
\hline Labour practices & $\begin{array}{l}\text { Issue 1: Employment and employment relationships } \\
\text { Issue 2: Conditions of work and social protection } \\
\text { Issue 3: Social dialogue } \\
\text { Issue 4: Health and safety at work } \\
\text { Issue 5: Human development and training in the workplace }\end{array}$ \\
\hline The environment & $\begin{array}{l}\text { Issue 1: Prevention of pollution } \\
\text { Issue 2: Sustainable resource use } \\
\text { Issue 3: Climate change mitigation and adaptation } \\
\text { Issue 4: Protection of the environment, biodiversity and restoration of } \\
\text { natural habitats }\end{array}$ \\
\hline Fair operating practices & $\begin{array}{l}\text { Issue 1: Anti-corruption } \\
\text { Issue 2: Responsible political involvement } \\
\text { Issue 3: Fair competition } \\
\text { Issue 4: Promoting social responsibility in the value chain } \\
\text { Issue 5: Respect for property rights }\end{array}$ \\
\hline Consumer issues & $\begin{array}{l}\text { Issue 1: Fair marketing, factual and unbiased information and fair } \\
\text { contractual practices } \\
\text { Issue 2: Protecting consumers' health and safety } \\
\text { Issue 3: Sustainable consumption } \\
\text { Issue 4: Consumer service, support, and complaint and dispute resolution } \\
\text { Issue 5: Consumer data protection and privacy } \\
\text { Issue 6: Access to essential services } \\
\text { Issue 7: Education and awareness }\end{array}$ \\
\hline $\begin{array}{l}\text { Community involvement } \\
\text { and development }\end{array}$ & $\begin{array}{l}\text { Issue 1: Community involvement } \\
\text { Issue 2: Education and culture } \\
\text { Issue 3: Employment creation and skills development } \\
\text { Issue 4: Technology development and access } \\
\text { Issue 5: Wealth and income creation } \\
\text { Issue 6: Health } \\
\text { Issue 7: Social investment }\end{array}$ \\
\hline
\end{tabular}

\section{Teori Legitimasi}

Penelitian ini menggunakan teori legitimasi karena salah satu tujuan yang ingin dicapai adalah hasil dari upaya TWC melalui divisi PKBL untuk memperluas area legitimasi perusahaan dengan publiknya. Teori Legitimasi menyangkut hal-hal seperti (Hadi, 2014):

1. Strategi perusahaan dalam upaya memposisikan diri di tengah lingkungan masyarakat yang semakin maju. Melaksanakan program CSR yang efektif membutuhkan kesadaran dari perusahaan bahwa keberadaannya terletak di tengah-tengah lingkungan masyarakat. Perusahaan tidak bisa menunjukkan sikap tidak peduli kepada masyarakat karena mereka juga bagian dari masyarakat itu sendiri.

2. Keberpihakan orang dan kelompok orang yang sangat peka terhadap gejala lingkungan sekitarnya. Teori Legitimasi muncul karena tumbuhnya kesadaran dari masyarakat atau kelompok orang yang merasa bahwa tanggung jawab terhadap sosial dan lingkungan juga harus dimiliki oleh perusahaan-perusahaan, tidak hanya oleh masyarakat atau pemerintah saja. Tuntutan dari kelompok orang yang peduli dengan gejala lingkungan di mana perusahaan berdiri menjadi dasar mengapa CSR perlu dilakukan dengan basis pencapaian legitimasi. Di slide yang berbeda akan dijelaskan apa itu "legitimasi" dan bagaimana mencapainya. 
3. Sesuatu yang diberikan masyarakat kepada perusahaan dan sesuatu yang diinginkan atau dicari perusahaan dari masyarakat. Mungkin pernyataan ini bisa dikatakan bahwa keberadaan perusahaan dan masyarakat sepatutnya berbasis simbiosis mutualisme. Namun, kenyataannya tidak semudah atau sesederhana itu. Memenuhi segala keinginan masyarakat bukan berarti suatu solusi bagi perusahaan untuk mencapai legitimasi.

4. Legitimasi mengalami pergeseran bersamaan dengan perubahaan dan perkembangan lingkungan dan masyarakat di mana perusahaan berada. Kebutuhan dan kapasitas turut berubah seiring dengan perkembangan zaman (lingkungan dan sosial). Hal ini yang menjadi pekerjaan besar bagi perusahaan untuk mampu menyesuaikan diri dengan perkembangan kebutuhan yang ada (dapat dipengaruhi oleh kebijakan pemerintah yang berganti, situasi ekonomi global, dsb).

Menurut Wartick \& Mahon (1994), ada tiga penyebab terjadinya jarak legitimasi, yaitu:

1. Ada perubahan dalam kinerja perusahaan tetapi harapan masyarakat terhadap kinerja perusahaan tidak berubah. Maksudnya di sini adalah, perusahaan tidak melakukan komunikasi yang rutin dan efektif dengan masyarakat sehingga ketika perusahaan mengalami perubahan pada aktivitas-aktivitas sosialnya, masyarakat justru tidak merasa butuh perubahan-perubahan tersebut. Dengan kata lain, aktivitas perusahaan tidak sejalan dengan kondisi di masyarakat.

2. Kinerja perusahaan tidak berubah tetapi harapan masyarakat terhadap perusahaan telah berubah. Maksudnya di sini adalah kebalikan dari situasi di poin 1 di atas. Perusahaan tidak melakukan perubahan seiring dengan perubahan atau perkembangan yang terdapat di masyarakat. Seperti yang sempat disebutkan di slide sebelumnya bahwa komunikasi dengan masyarakat merupakan ilmu sosial di mana masyarakat adalah sekumpulan manusia yang dinamis. Dinamika sosial berubah seiring dengan waktu dan situasi internal dan eksternal lingkungan masyarakat itu sendiri.

3. Kinerja perusahaan dan harapan masyarakat berubah ke arah yang berbeda, atau ke arah yang sama tetapi waktunya berbeda. Maksud dari poin ini adalah perusahaan dan masyarakat sama-sama mengalami perubahan aktivitas dan harapan tetapi tidak ke arah yang sama. Hal ini yang kemudian harus dicermati oleh pihak atau bagian komunikasi perusahaan. Baik itu di bawah bagian Public Relations atau Community Relations, atau lainnya, perusahaan harus melakukan komunikasi yang intensif dan efektif sehingga perubahan aktivitas dan harapan tidak berselisih.

\section{METODE PENELITIAN}

\section{A. Rancangan Penelitian}

Penelitian ini menggunakan pendekatan kualitatif yang berbentuk studi kasus. Peneliti memutuskan untuk menggunakan pendekatan kualitatif karena dirasa paling tepat dalam mendapatkan pemahaman yang mendalam atas suatu fenomena atau kasus. Poerwandari (2001) mengatakan, untuk mendapatkan pemahaman yang mendalam dan khusus atas suatu fenomena serta untuk dapat memahami manusia dalam segala kompleksitasnya sebagai makhluk subjektif, pendekatan kualitatif merupakan metode yang paling sesuai untuk digunakan.

Penelitian studi kasus ini menggunakan suatu pendekatan yang bertujuan untuk mempertahankan keutuhan dari objek penelitian. Data yang terkumpul dipelajari sebagai satu kesatuan yang tujuannya adalah untuk mengembangkan pengetahuan yang mendalam mengenai objek yang diteliti.

1. Jumlah Subjek Penelitian

Pada dasarnya penelitian kualitatif studi kasus tidak memfokuskan diri pada jumlah subjek penelitian melainkan kedalaman dan proses penelitian (Poerwandari, 2001). Dalam penelitian ini peneliti berencana mengadakan wawancara Kepala divisi PKBL TWC (1 orang).

2. Sumber Data

Sumber data dalam penelitian ini diperoleh tidak hanya dari informan/subjek penelitian seperti yang telah disebut di atas tetapi juga melibatkan studi dokumentasi yang merekam proses pelaksanaan program CSR yang tercatat selama 2017-2018 yang menjadi objek penelitian dalam penelitian ini. Studi dokumentasi diperlukan untuk mencari tahu catatan-catatan yang mungkin sempat menjelaskan hambatan-hambatan selama proses pelaksanaan program CSR-nya.

\section{HASIL PENELITIAN}

Penelitian dilaksanakan dengan dua teknik yaitu teknik wawancara melalui korespondensi surat elektronik (surel) dengan Bpk. Bambang Sarwo Eddy selaku Manajer Divisi Program Kemitraan dan Bina Lingkungan (PKBL) PT Taman Wisata Candi Borobudur, Prambanan dan Ratu Boko (Persero) atau disingkat TWC, dan teknik studi dokumentasi kegiatan-kegiatan atau pelaksanaan program yang telah dilakukan oleh PKBL TWC. 


\section{A. TWC sebagai Organisasi}

Sebagai perusahaan BUMN, TWC awalnya berdiri dengan nama PT Taman Wisata Candi Borobudur dan Prambanan (Persero) dengan dasar hukum PP No. 7 Tahun 1980. Lalu, melalui Keputusan Presiden Replublik Indonesia No. 1 Tahun 1992 tentang Pengelolaan Taman Wisata Candi Borobudur, Prambanan, serta Pengendalian Lingkungannya, saat itu TWC (tanpa Kawasan Ratu Boko) diberikan wewenang penuh untuk mengelola taman-taman wisata tersebut. Tepatnya tahun 1994, Kawasan Ratu Boko menjadi bagian dari TWC sehingga namanya menjadi PT Taman Wisata Candi Borobudur, Prambanan dan Ratu Boko (Persero).

Adapun visi dan misi dari TWC (Corporate Borobudur Park, 2019) adalah

- Visi

Menjadi pengelola dan pengembang cagar budaya dan destinasi pariwisata yang unggul di Indonesia

\section{- Misi}

Mengelola dan mengembangkan lingkungan cagar budaya agar selaras dengan upaya pelestariannya

Mengelola dan mengembangkan lingkungan destinasi pariwisata secara berkelanjutan

Memberdayakan masyarakat sekitar kawasan yang dikelola perusahaan

Menjalankan usaha yang berdaya saing, kreatif, inovatif, dan ramah lingkungan

\section{B. Divisi PKBL sebagai Organisasi}

PKBL merupakan salah satu divisi yang berdiri di bawah sekretaris perusahaan dan sudah berjalan fungsinya sejak tahun 1994 berdasarkan UU Tahun 2003 tentang BUMN. Pada awal pembentukan divisi ini nama yang digunakan adalah Program Usaha Kecil dan Koperasi (PUKK). Sejak tahun 2012, nama PUKK mengalami pergantian menjadi PKBL. Sebagai divisi, PKBL memiliki visi 'meningkatkan kemampuan usaha kecil agar menjadi tangguh \& mandiri' dan misi 'membantu pemerintah dalam pengentasan kemiskinan \& pembangunan daerah'.

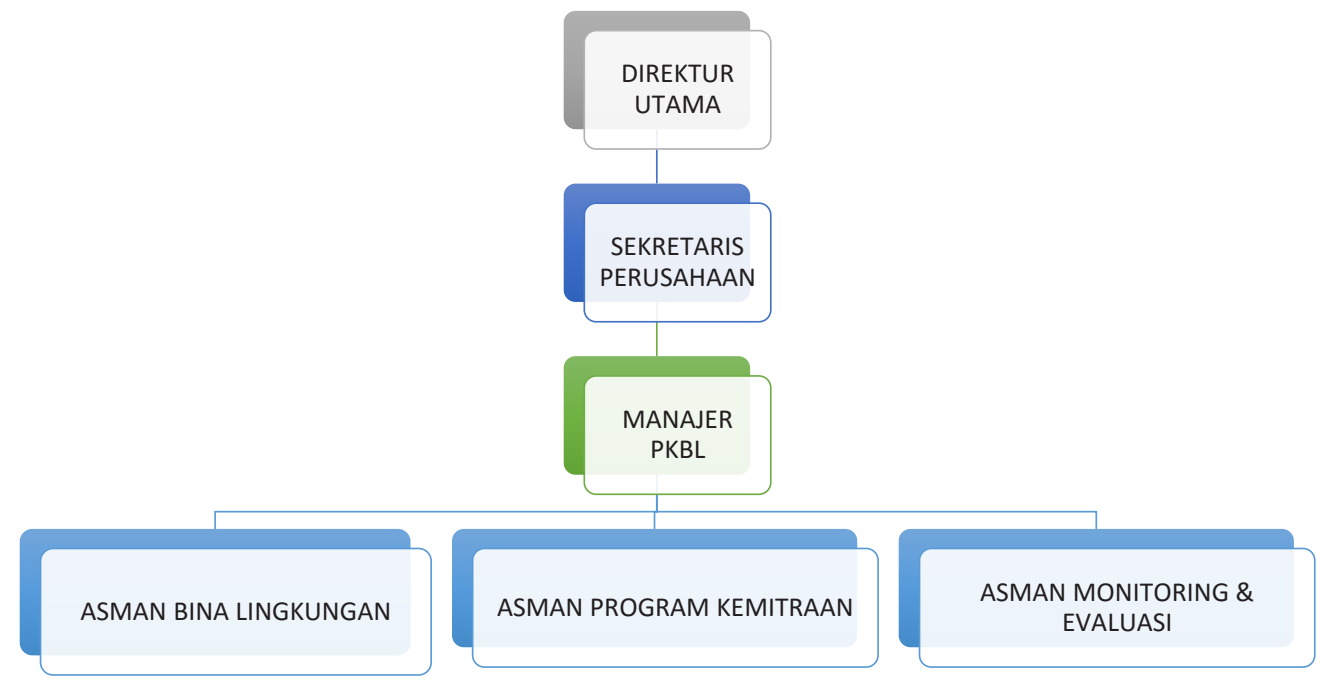

Figur 1. Struktur Organisasi Divisi PKBL

PKBL, melalui subdivisi Kemitraan memiliki tujuh sektor meliputi industri, perdagangan, pertanian, perkebunan, peternakan, perikanan, dan jasa. Sedangkan subdivisi Bina Lingkungan, terdapat tujuh sektor yang berbeda meliputi bencana alam, pendidikan, peningkatan kesehatan, sarana dan prasarana umum, sarana ibadah, pelestarian alam, dan sosial kemasyarakatan.

Struktur organisasi PKBL di atas menjelaskan posisi divisi PKBL di dalam organisasi TWC. Selain itu, struktur di atas juga turut memberikan gambaran fokus perhatian dari divisi ini, meliputi Bina Lingkungan, Program Kemitraan, dan Monitoring \& Evaluasi. Menariknya, Program Kemitrran dan Bina Lingkungan dibagi menjadi dua fungsi manajemen yang berbeda, terlebih lagi dengan adanya fungsi manajemen Monitoring dan Evaluasi yang terpisah. Meskipun begitu, fungsi manajemen Monitoring dan Evaluasi tidak terpisah dari subdivsi yang lain melainkan melakukan monitoring dan evaluasi terhadap subdivisi Bina Lingkungan dan Program Kemitraan secara khusus, dan terhadap divisi PKBL secara umum. 


\section{Penyusunan dan Tujuan Program PKBL}

Program-program PKBL disusun berdasarkan Rencana Kerja dan Anggaran (RKA) yang disetujui pada saat pelaksanaan Rapat Umum Pemegang Saham (RUPS). Program PKBL sendiri dirancang di dalam forum rapat dengan pimpinan (Direktur Utama, Sekretaris Perusahaan) dan karyawan PKBL serta melibatkan Kementerian BUMN.

Untuk program-programnya sendiri, PKBL memiliki program rutin harian, mingguan, bulanan dan tahunan. Dengan kata lain, terdapat program jangka pendek dan panjang yang melibatkan periode waktu lebih dari satu tahun. PKBL memiliki tujuan yang ingin dicapai melalui pelaksanaan program-programnya, yaitu secara umum untuk meningkatkan perekonomian bagi masyarakat sekitar perusahaan, serta menunjang pembangunan di wilayah sekitar perusahaan.

\section{Perencanaan Program PKBL}

Perancangan program dilakukan berdasarkan pedoman pada sektor-sektor yang ada dan dipilih berdasarkan program yang paling dibutuhkan bagi masyarakat. Pemilihan program yang paling dibutuhkan disesuaikan dengan keadaan pada tahun dijalankannya program sehingga terdapat kesesuaian juga dengan harapan masyarakat dan pemerintah. Dalam proses ini, PKBL menjaring isu-isu yang didapatkan di masyarakat. Tidak selamanya PKBL memenuhi segala permohonan dari masyarakat, namun juga menolak sesuai dengan dan dan kebutuhan yang diperlukan dan konsekuensi dari para mitra.

\section{Pelaksanaan Program PKBL}

Seperti yang telah disebutkan sebelumnya bahwa tujuan dari divisi PKBL adalah untuk meningkatkan perekonomian bagi masyarakat sekitar perusahaan, serta menunjang pembangunan di wilayah sekitar perusahaan. Dalam pelaksanaannya, untuk mengukur keberhasilan program adalah melihat apakah terjadi peningkatan perekonomian dan peningkatan pembangunan bagi masyarakat sekitar perusahaan. Selain itu, dari deskripsi tujuan tersebut, masyarakat sekitar perusahaan menjadi subyek fokus pelaksanaan program.

Adapun program-program yang dijalankan bersifat harian, mingguan, bulanan, dan tahunan. Untuk program harian, PKBL menerima angsuran dari para mitra binaan, dan mencatat ke dalam buku kas pembantu mitra binaan lalu memasukkan ke dalam program yang telah terkomputerisasi. Selain itu, PKBL turut menerima dan memasukkan surat disposisi dari sekretariat untuk diteruskan ke masing-masing divisi. Untuk program mingguan, PKBL melakukan penagihan-penagihan kepada mitra binaan yang mempunyai tunggakan 'macet' 'diragukan dan kurang lancar', dan 'bermasalah' guna mengantisipasi tunggakan yang semakin banyak. Selain itu, setiap bulannya, divisi ini melakukan survei kepada calon mitra binaan baru dan melakukan kunjungan/survei kepada calon mitra yang akan menerima hibah serta menyalurkan bantuan hibah kepada mitra yang telah mendapat persetujuan dari atasan. Program lain yang dijalankan secara mingguan adalah melakukan pendampingan pelatihan sepak bola yang dilaksanakan seminggu dua kali yaitu Sabtu dan Minggu.

Untuk program bulanan, PKBL melakukan program berupa penyaluran bantuan pinjaman lunak kepada mitra binaan baru maupun lama serta membuat surat perjanjian pinjaman kepada mitra binaan dan memonitor ke lapangan terhadap pembangunan fisik yang telah dikerjakan sebelumnya oleh PKBL, sehingga akan mendapatkan hasil yang sempurna. Selain itu, program sosial yang dilaksanakan tiap bulan berupa pengajian rutin Ahad Legi dengan masyarakat sekitar perusahaan. Secara tahunan, PKBL menjalankan program yang telah disusun pada tahun sebelumnya yang juga meliputi program-program harian, mingguan dan bulanan. Adapun program tahunan yang dilaksanakan berupa Paket Ramadhan, Safari Ramadhan, Mudik Gratis, Bazar Murah, Bedah Rumah RLTH, Siswa Berprestasi, dan lain sebagainya.

\section{Dampak Program PKBL}

Melalui program-programnya PKBL menciptakan dampak yang dapat dirasakan oleh masyarakat. Hal ini sesuai dengan tujuan dari pelaksanaan program PKBL itu sendiri yaitu meningkatkan perekonomian bagi masyarakat sekitar perusahaan, serta menunjang pembangunan di wilayah sekitar perusahaan. Beberapa dampaknya di antaranya: berhasil meningkatkan keuntungan pelaku usaha baik dari segi penjualan, pemasaran, dan jumlah tenaga kerja yang terserap turut bertambah banyak. Dampak dari program-program PKBL sangat dirasakan manfaatnya bagi masyarakat dan dapat meluas kepada pemerintah.

\section{PEMBAHASAN PENELITIAN}

PT TWC sebagai BUMN mendukung program "BUMN Hadir Untuk Negeri". Hal ini tercermin melalui mediamedia sosial yang digunakan sebagai penyaluran informasi kepada publik. Hampir dalam setiap publikasinya baik berupa foto maupun video, tercantum \#BUMNhadiruntuknegeri. Upaya PKBL juga sesuai dengan tujuan yang telah ditetapkan dalam perumusan program umumnya yaitu mendekatkan diri dengan masyarakat sekitar perusahaan. Pendekatan diri dilakukan melalui pemberian bantuan kepada manusia dan lingkungan hidup. Dalam teori mengenai tanggung jawab sosial perusahaan, perusahaan memang sebaiknya mengutamakan masyarakat (manusia dan lingkungan hidup) sekitar 
perusahaan yang terdekat untuk dijadikan sasaran program tanggung jawab sosialnya. Dampak riil harus dirasakan oleh masyarakat sejak hadirnya perusahaan di tengah-tengah lingkungan mereka.

\section{A. Identifikasi Isu}

PT TWC melalui PKBL sebagai divisi tanggung jawab sosial perusahaan cenderung fokus pada pemberian bantuan fisik berupa renovasi atau pembangunan ulang rumah tidak layak huni (RLTH) bagi keluarga atau anggota masyarakat yang kurang mampu, penanaman bibit pepohonan, pemberian bantuan kepada siswa berprestasi, dan lainnya. Program-program yang telah dijalankan atau yang dalam rumusan perancangan dimulai dari proses identifikasi isu. Menurut Kriyantono (2015) aktivitas organisasi pasti memengaruhi aktivitas masyarakat, sebaliknya masyarakat sebagai lingkungan sosial akan memengaruhi aktivitas organisasi, dan dengan mengetahui isu-isu potensial, organisasi dapat menyiapkan strategi yang tepat dengan memanfaatkan isu tersebut guna meningkatkan reputasi.

Regester \& Larkin (2008) dan Seitel (2001) mengenalkan istilah "outside-in thinking" atau "plan from the outside in" yang berarti strategi disusun berdasarkan isu-isu yang ditemukan di lingkungan eksternal organisasi. Seperti disebutkan sebelumnya bahwa PKBL melakukan proses identifikasi isu dengan menerima masukan-masukan dari masyarakat berupa permohonan yang mana kemudian tidak semua permohonan direalisasikan, namun dipilih berdasarkan tingkat prioritas atau apa yang paling dibutuhkan saat itu. Hal ini cukup membuktikan bahwa PKBL melakukan pendekatan outside-in thinking di mana permohonan-permohonan dari masyarakat diterima untuk dijadikan pertimbangan program organisasi.

\section{B. Tanggung Jawab Sosial Perusahaan}

Penelitian ini menemukan bahwa PKBL melakukan program-program sosial meliputi:

1. Pembangunan rumah layak huni bagi masyarakat

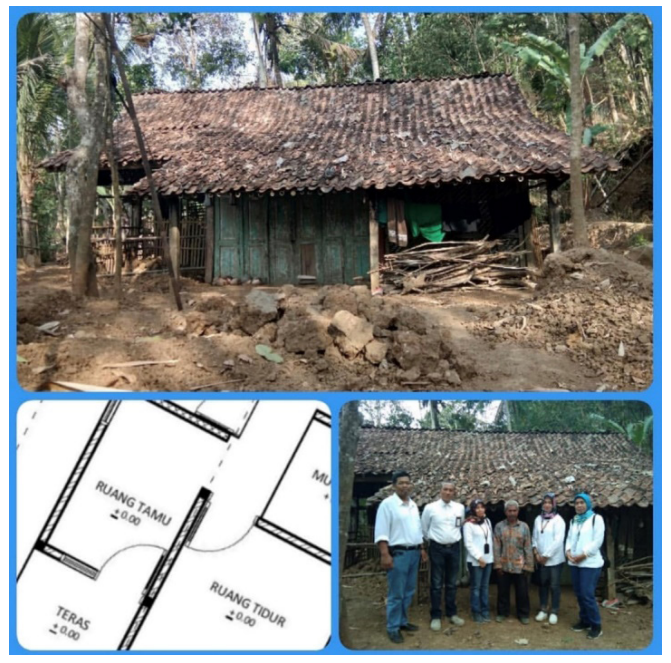

Gambar 1. Kunjungan Lokasi Pembangunan Ulang untuk Rumah Tidak Layak Huni

2. Penanaman bibit pepohonan dan tanaman

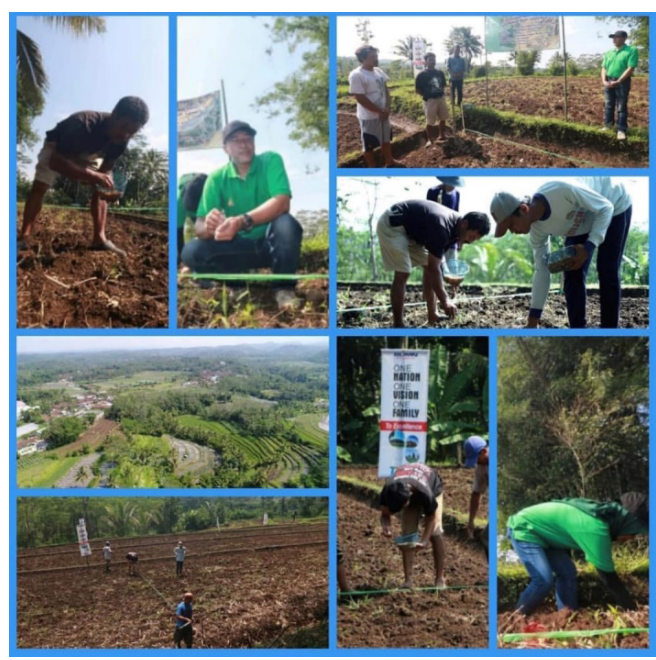

Gambar 2. Penanaman Biji Jagung 
3. Pengundangan anak yatim untuk berkunjung ke Yogyakarta

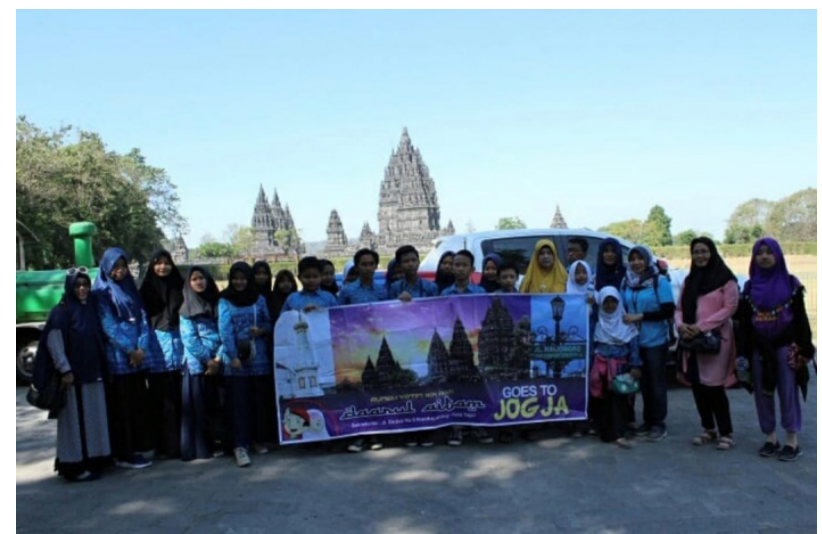

Gambar 3. Rumah Yatim Non Panti Da'arul Aitam Kota Tegal Goes to Jogja bersama PT. TWC

4. Pemberian sarana pendidikan kepada sekolah

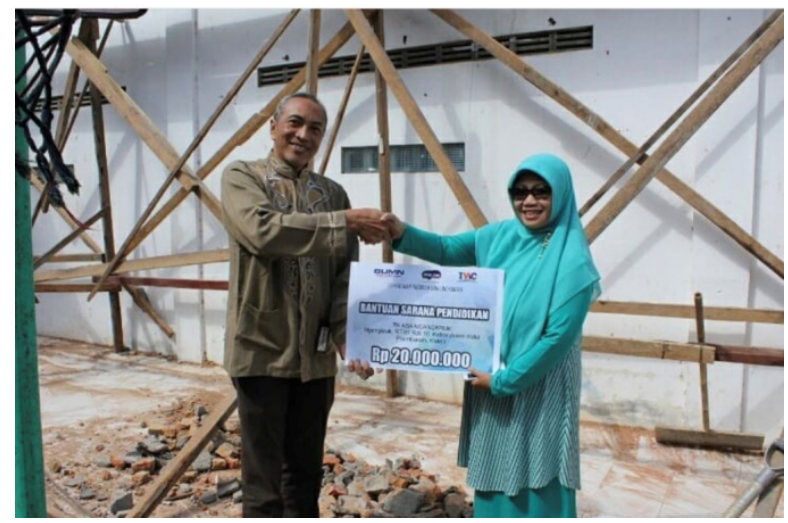

Gambar 4. Bantuan Sarana Pendidikan kepada TK Aisyiyah Bustanul Athfal (ABA) Ngangkruk

5. Pemberian apresiasi kepada siswa berprestasi

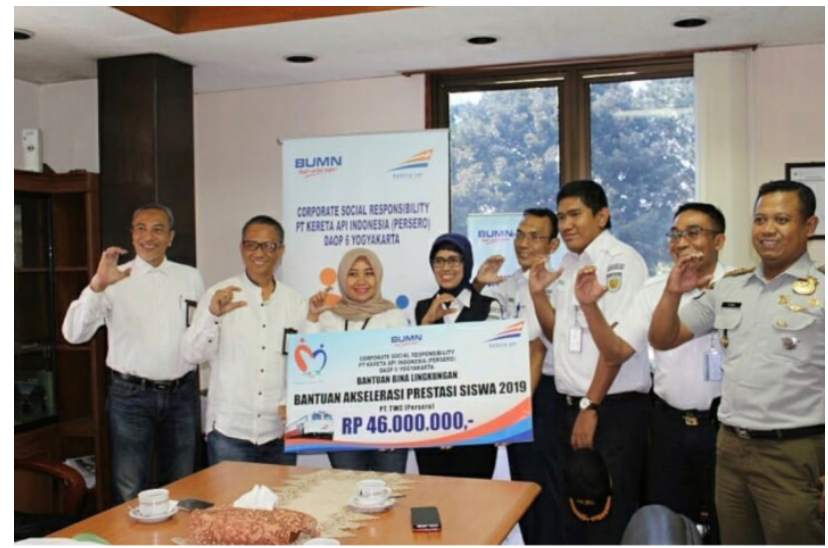

Gambar 5. Sinergi Program Prestasi Siswa PT. TWC dengan PT. KAI 
6. Pembagian paket pangan murah sebagai kontribusi program BUMN di seluruh Indonesia

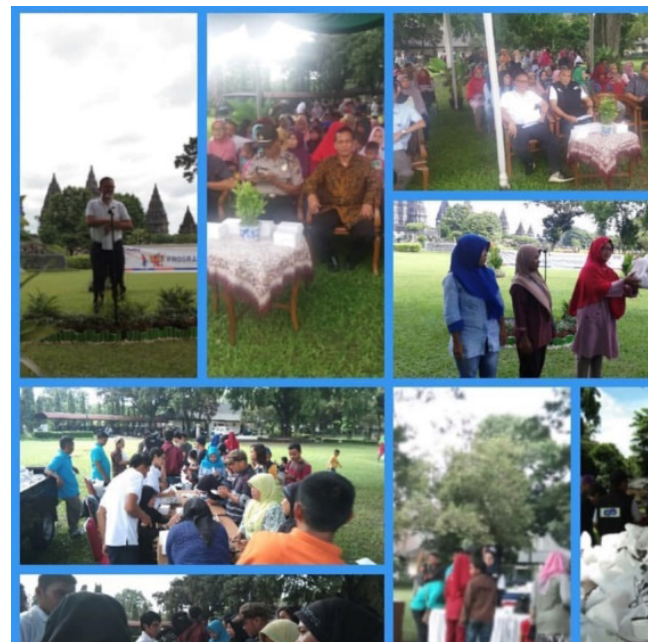

Gambar 6. PT TWC melaksanakan Gebyar Paket Pangan Murah BUMN

7. Pemberian santunan kepada anak yatim piatu

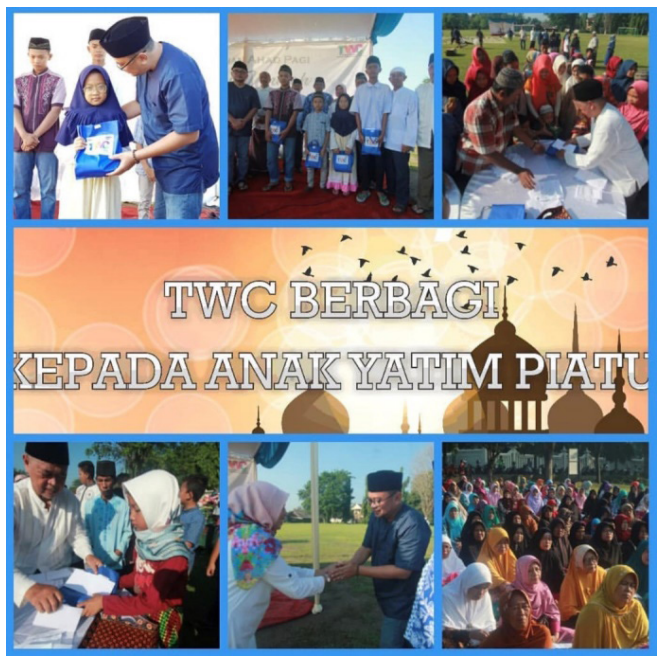

Gambar 7. Santunan kepada Anak Yatim Piatu di Lapngan Rakai Pikatan bersama Khoiru Ummah

8. Pemberian bantuan untuk pembangunan tempat ibadah

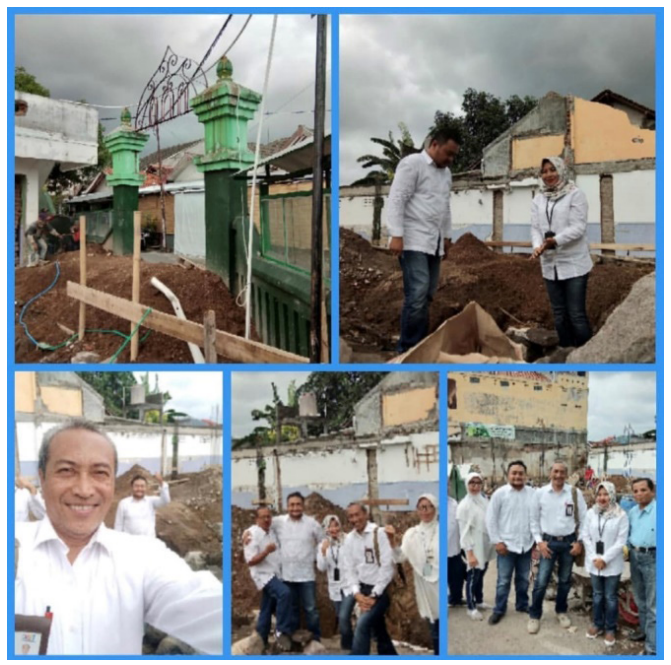

Gambar 8. Pemberian Bantuan kepada Pengurus Mesjid Al Hakim Jeruklegi, Banguntapan, Bantul 
9. Pemberian rumah layak huni bagi karyawan PT. TWC

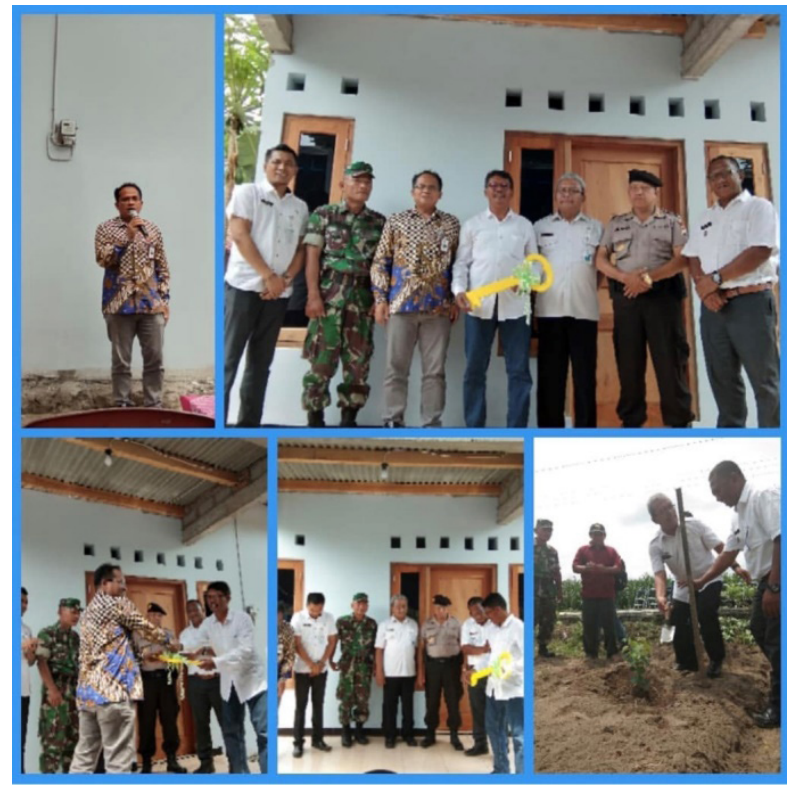

Gambar 9. Penyerahan Kunci Rumah kepada Karyawan PT. TWC di Dusun Beji, Desa Kemudo

Berdasarkan hasil penelitian di atas sebagian besar kegiatan tanggung jawab sosial perusahaan PT TWC melalui Divisi PKBL bersifat bantuan kepada masyarakat. Jika dikaitkan dengan teori yang digunakan di dalam penelitian ini, investasi sosial dilakukan melalui kegiatan filantrofi. Disebutkan bahwa investasi sosial melalui kegiatan tanggung jawab sosial perusahaan tidak dilakukan untuk meraup keuntungan finansial bagi perusahaan (KPMG Internasional, 2014). Dari lima definisi yang ada mengenai investasi sosial yang ditawarkan oleh KPMG Internasional (2014), PT TWC menyentuh empat, di antaranya investasi dalam bentuk donasi berupa uang tunai, investasi yang ditujukan kepada rekan perusahaan tanpa basis profit, investasi dalam bentuk program yang diharuskan oleh pemerintah melalui dukungan program BUMN Hadir Untuk Negeri, dan investasi yang dilakukan secara lokal atau dekat dengan aktivitas operasional perusahaan.

Mengacu pada ISO 26000:2010 di mana terdapat enam subyek inti yang menjadi pembahasan mengenai tanggung jawab sosial (perusahaan), PT TWC melalui Divisi PKBL menyentuh tiga subyek inti, seperti

1. Human rights atau HAM melalui pemberian bantuan untuk pembangunan tempat ibadah dan santunan bagi anak-anak yatim piatu;

2. The environment atau lingkungan hidup melalui program penanaman pohon;

3. Community involvement and development atau pengembangan masyarakat melalui pemberian bantuan bagi siswa berprestasi dan pemberangkatan siswa-siswi terpilih melalui proses seleksi untuk diikutkan program SMN (Siswa Mengenal Nusantara) di Propinsi Riau

Pembahasan program tanggung jawab sosial perusahaan oleh PT TWC melalui Divisi PKBL juga menyentuh poin-poin yang terdapat dalam teori Legitimasi. PT TWC mengawali program melalui proses perencanaan yang dilakukan dengan menyusun RKA dan disetujui pada RUPS. Untuk menyusun RKA dan poin program, tim PKBL melakukan proses identifikasi isu-isu yang ada di masyarakat yang kemudian dijadikan bahan program sosial. PT TWC mengidentifikasi isu secara internal (program sosial bagi pegawai) dan eksternal perusahaan (program sosial bagi pemangku kepentingan eksternal). Teori Legitimasi mencakup bagaimana perusahaan memposisikan diri di tengah-tengah masyarakat dengan menyesuaikan kebutuhan masyarakat berserta perubahan-perubahannya tanpa meninggalkan kapasitas yang dimiliki oleh perusahaan (Hadi, 2014). Hal ini dilakukan secara strategis agar tidak timbul jarak antara perusahaan dan masyarakat. PT TWC melalukan proses identifikasi isu dengan mempertimbangkan kebutuhan masyarakat meskipun masyarakat tidak dilibatkan dalam proses perumusan rencana program sosial.

\section{KESIMPULAN DAN SARAN}

PT TWC melalui Divisi PKBL melaksanakan tanggung jawab sosial perusahaan atas dasar pendekatan diri dengan masyarakat. Sejumlah jenis program sosial dilakukan baik yang ditujukan bagi eksternal perusahaan maupun internal perusahaan. Sebagian besar program sosial yang telah diadakan bersifat filantrofis di mana perusahaan memberikan bantuan kepada masyarakat yang menjadi sasaran program tanpa berorientasi pada peningkatan kondisi keuangan perusahaan. Untuk masalah publikasi, melalui media-media sosial yang mudah diakses, PT TWC membagikan informasi mengenai program-program sosial yang telah dilaksanakan sehingga masyarakat luas turut mengetahui sekaligus menjadi 
bentuk transparansi informasi perusahaan.

Program-program tanggung jawab sosial perusahaan PT TWC sudah cukup mencakup teori-teori yang membahas secara ideal mengenai konsep tanggung jawab sosial. Dari lima definisi tanggung jawab sosial perusahaan yang ditawarkan oleh KPMG International, PT TWC telah mencakup empat poin. Dari enam poin atau subyek inti tanggun jawab sosial yang terdapat dalam ISO 26000:2010, PT TWC telah mencakup tiga poin. Selain itu, program-program tanggung jawab sosial perusahaan PT TWC telah mencakup apa yang menjadi bahasan dalam teori Legitimasi terutama pada poin bagaimana perusahaan melakukan proses identifikasi isu ketika menyusun RKA dan sebelum disetujui pada RUPS.

Secara umum, PT TWC melalui Divisi PKBL telah dengan baik melakukan program tanggung jawab sosial perusahaan dengan indikator seperti: program telah menyentuk isu internal dan eksternal perusahaan, program cukup beragam mulai dari pendidikan sampai perhatian terhadap lingkungan. Selain itu, PT TWC telah memberikan kontribusi terhadap program nasional melalui dukungannya untuk gerakan BUMN Hadir Untuk Negeri. Untuk masalah publikasi pun, PT TWC menggunakan media-media sosial yang mudah diakses oleh masyarakat luas. Akan tetapi, ada beberapa hal yang perlu menjadi perhatian guna meningkatkan kualitas kinerja PKBL yang sudah ada.

Pertama, PT TWC lebih fokus pada program sosial yang bersifat filantrofis. Pendekatan ini tidak buruk namun cukup konvensional. Tren program tanggung jawab sosial perusahaan saat ini lebih mengarah pada poin-poin yang tercakup dalam rumusan Sustainable Development Goals (SDGs) yang mana keterlibatan perusahaan lebih dari sekedar filantrofi dari perusahaan. Kedua, meskipun isu lingkungan telah disentuh melalui program penanaman pohon, program ini tidak cukup relevan dengan aktivitas perusahaan. Akan menjadi lebih relevan jika PT TWC memberikan perhatian pada kegiatan lingkungan di sekitar area taman wisata candi seperti isu sampah. Isu sampah tidak hanya terkunci ada kebersihan lingkungan tapi juga dapat difokuskan pada pemanfaatan sampah untuk lingkungan internal area wisata candi. Dengan begitu, sampah yang dihasilkan di dalam lingkungan area PT TWC benar-benar menjadi tanggung jawab perusahaan sampai pada tahap terakhir dari siklus manajemen sampah.

Ketiga, dari enam poin yang menjadi subyek inti dalam ISO 26000:2010 PT TWC mencakup sedikitnya tiga subyek. Sebaiknya program-program yang bersifat internal, seperti yang menyangkut kesejahteraan pegawai melalui kebijakan mengenai buruh, menyangkut kebijakan anti korupsi, atau proteksi keamanan dan keselamatan bagi pengunjung juga turut dibahas sebagai program tanggung jawab sosial perusahaan. Dengan begitu, poin-poin dalam ISO yang ada terpenuhi sepenuhnya.

Terakhir, PT TWC sebaiknya melibatkan secara aktif anggota atau perwakilan dari masyarakat ketika tengah merumuskan program-program sosial sebelum dilakukan persetujuan pada RUPS. Hal ini akan secara efektif menyasar masyarakat yang menjadi prioritas serta isu-isu yang lebih penting untuk dijadikan perhatian perusahaan. Tidak kemudian segala masukan dari anggota masyarakat harus disetujui oleh perusahaan namun harus ditemukan titik tengah dengan menyesuaikan kapasitas perusahaan.

\section{DAFTAR PUSTAKA}

Afiansyah, Arba'in Ridho. (2015). Pelaksanaan Tanggung Jawab Sosial Perusahaan (CSR) PT. Pelabuhan Indonesia III (Persero). Privat Law, Vol. III, No. 2, Juli-Desember 2015.

Hadi, N. (2014). Corporate Social Responsibility. Yogyakarta: GRAHA ILMU.

ISO 26000:2010

Mulyana, D. (2004). Metodologi Penelitian Kualitatif Edisi Revisi. Bandung: PT Remaja Rosidakarya.

Poerwandari, K. (2001). Pendekatan Kualitatif Untuk Penelitian Perilaku Manusia. Universitas Indonesia, Fakultas Psikologi. Jakarta: Lembaga Pengembangan Sarana Pengukuran dan Pendidikan Psikologi (LPSP3).

Porter dan Kramer (2002) [Porter, Michael E. dan Kramer, Mark R. (2002). The Competitive Advantage of Corporate Philanthropy. Harvard Business Review, December.

Robbins, S., \& Coutler, M. (2010). Manajemen. Jakarta: Erlangga.

Soehartono, I. (1995). Metode Penelitian Sosial. Bandung: PT Remaja Rosdakarya.

Sujanto, Raditia Y. (2018). Efektivitas Csr Dalam Mengantisipasi Krisis Melalui Pendekatan Investasi Sosial (Program Csr "Masak Besar 2.705 Porsi Nasi Goreng” Jogja City Mall). Channel: Jurnal Komunikasi, Vol. 5, No.1.

Suryabrata, S. (1992). Metode Penelitian. Yogyakarta: University Gadjah Mada Press.

UU No.40 tahun 2007 tentang Perseoran Terbatas

Verčič, Dejan, dan Zerfass, Ansgar. (2016). Conspicuous Corporate Social Responsibility. Public Relations Journal, Vol. 10, No.1 (Summer 2016).

Wartick, Steve L. dan Mahon, John F. (1994). Toward a Substantive Definition of The Corporate Issue Construct. Business \& Society, Vol. 33 No. 3, December 1994 293-311. 
